\title{
The Upper Jurassic Blokelv-1 cored borehole in Jameson Land, East Greenland - an introduction
}

\author{
Morten Bjerager, Stefan Piasecki and Jørgen A. Bojesen-Koefoed
}

\begin{abstract}
The Geological Survey of Denmark and Greenland (GEUS) successfully drilled the fully cored Blokelv-1 borehole in the central part of the Jameson Land Basin in East Greenland, targeting the Upper Jurassic, rich source-rock interval of the Hareelv Formation. The borehole achieved 100\% core recovery from $1.72 \mathrm{~m}$ to a total depth of $233.8 \mathrm{~m}$; the recovered Hareelv Formation section consists of interlayered black, laminated organic-rich mudstones, massive sandstones and heterolithic sandstone-mudstone intervals of the Katedralen Member, and amalgamated massive sandstones of the Sjællandselv Member. The core is of very high quality and has been subjected to an extensive sampling and analytical programme focused particularly on petroleum geological aspects, as presented in the following eight papers in this volume. This bulletin describes an important, previously poorly documented member of the 'Kimmeridge Clay' family of prolific petroleum source rocks in the North Atlantic area.
\end{abstract}

Keywords: East Greenland, Jameson Land, Upper Jurassic, Hareelv Formation, cored borehole

Geological Survey of Denmark and Greenland, Øster Voldgade 10, DK-1350 Copenhagen K, Denmark. Email:mbj@geus.dk

The Blokelv-1 borehole was drilled by the Geological Survey of Denmark and Greenland (GEUS) in Jameson Land during the summer of 2008. It was the first of a series of fully cored boreholes planned as part of a collaborative project between GEUS and a number of sponsoring oil companies entitled Petroleum Geological Studies, Services and Data in East and North-East Greenland (BojesenKoefoed et al. 2009, 2014). The borehole is situated in the central, deep part of the Jurassic Jameson Land Basin near the Blokelv river, after which the borehole is named, c. $35 \mathrm{~km}$ west of the Constable Pynt airport (Fig. 1).

The borehole targeted a poorly exposed part of the Upper Jurassic Hareelv Formation that represents a midKimmeridgian sea-level highstand (Surlyk 2003) and is a correlative of the well-known Kimmeridge Clay Formation (sensu lato) of Northwest Europe; it was thus expected to include a rich petroleum source-rock interval. The North-East Greenland part of the Circum Arctic Resource Appraisal (CARA; Christiansen et al. 2006; Gautier 2007; Gautier et al. 2011) pointed out that the quality of an Upper Jurassic - Lower Cretaceous source rock in North-East Greenland should be considered a major risk element in assessing the petroleum potential of the region. Data based on outcrop sampling, however, have shown surprisingly low petroleum potential. A drilling programme that included the Blokelv- 1 borehole was thus designed to provide as complete coverage as possible of the entire Oxfordian to Ryazanian succession onshore East and North-East Greenland in order to better understand the geological context of the source rocks and to provide fresh and unweathered samples for new and comprehensive analyses of the entire succession.

The succession cored by the Blokelv-1 borehole covers the interval from the Middle Oxfordian to the Lower Volgian and in general terms the analytical programme included:

- Detailed sedimentological description and analysis, including interpretation of depositional environments represented by the deposits 
- Detailed biostratigraphic analysis, based on both palynomorphs (dinoflagellate cysts) and macrofossils (ammonites)

- Detailed analysis of the petroleum potential of mudstones, including richness, thermal maturity, biomarker and stable carbon isotopic fingerprints of source rocks and oil stains

- Detailed analysis of the reservoir properties of sandstones, including diagenetic studies

- Chemostratigraphy based on bulk geochemical analysis and provenance analyses of sandstones based on dating of detrital zircons

- Analysis of uplift history based on apatite fission track analysis (AFTA)

- Analysis of magmatic intrusions penetrated.
The results of the analytical programme have been previously reported to the group of sponsoring oil companies (Bjerager et al. 2009). Following the expiration of the 5-year confidentiality clause on 1 January 2015, the data were released for exclusive use by GEUS, and this bulletin presents the key results in a series of papers, each dealing with different aspects of the analyses.

\section{Drilling operations}

The drilling operation was organised by GEUS and comprised a camp of six persons, including two geologists, two technicians, one of whom also undertook catering, and two drillers. The drilling was part of a major field-

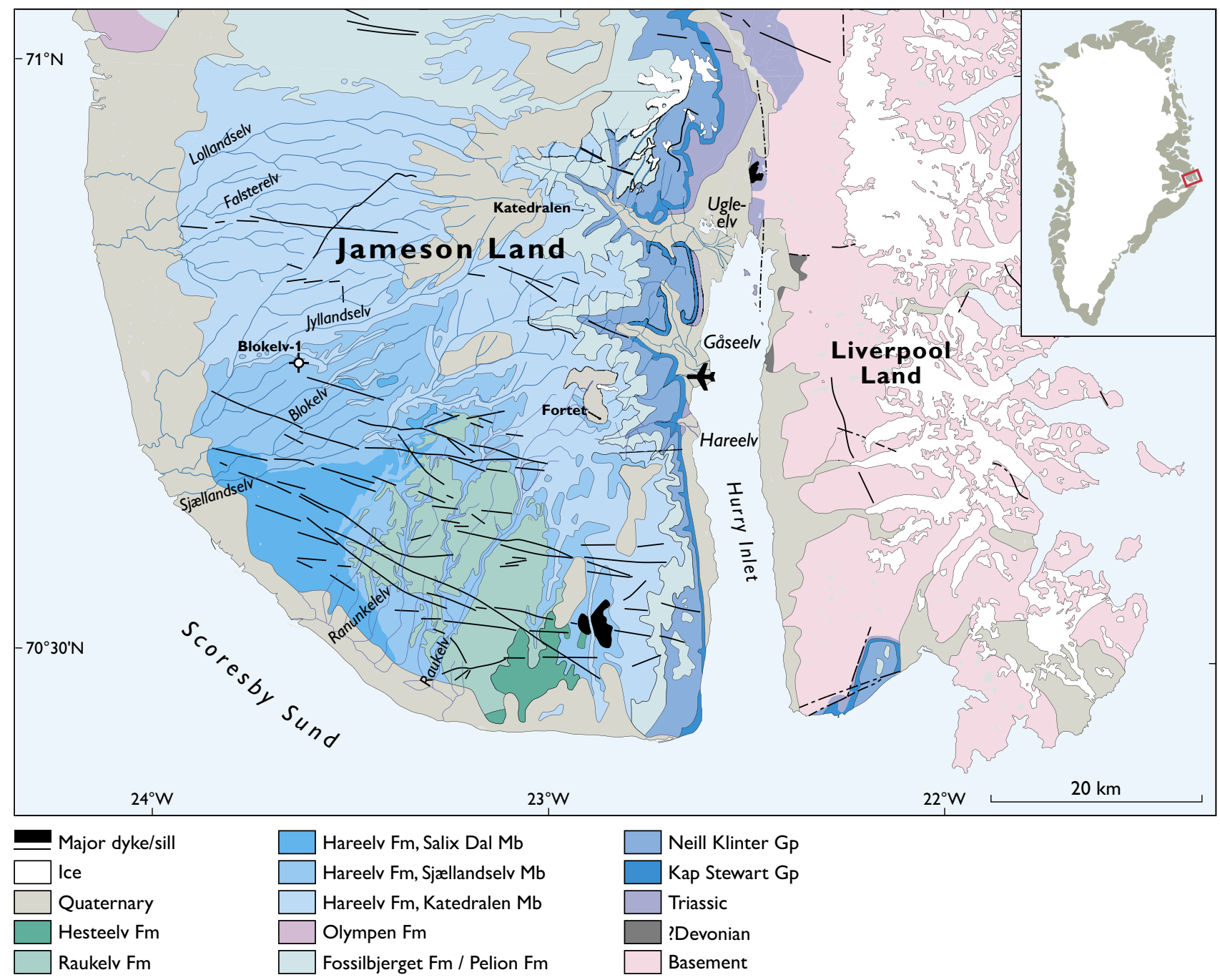

Fig. 1. Geological map of the southern part of Jameson Land showing the location of the Blokelv-1 borehole. Only named river systems are indicated. 

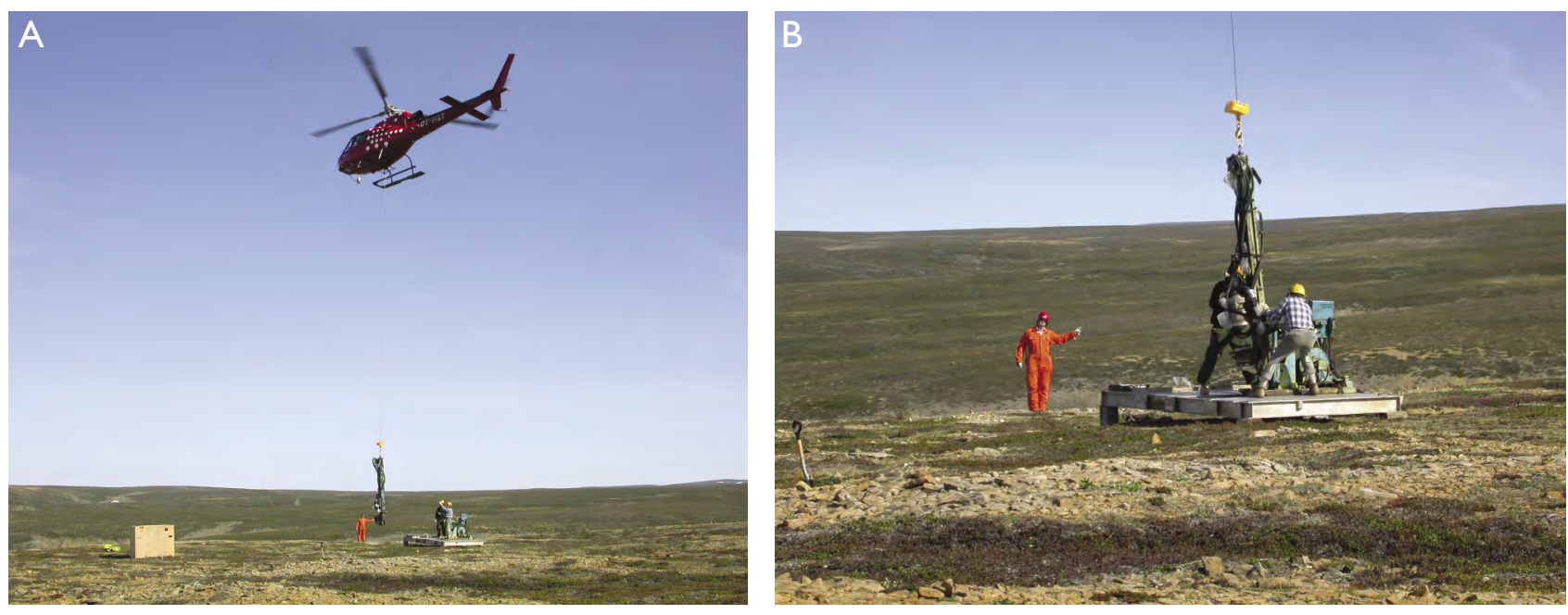

Fig. 2. Transport and erection of the Faxe Kalk A/S Diamant Boart 747 wireline rig; the rig was transported as helicopter sling loads (A) and the drill tower was assembled directly $(\mathbf{B})$.

work programme, and a helicopter was chartered for the full season.

Two days of reconnaissance prior to drilling ensured selection of the optimal location for the drill site, remote from exposed major sills and dykes. The disassembled drill-rig parts were flown as sling loads from the Constable Pynt airport to the Blokelv- 1 drill site at $70^{\circ} 45.305^{\prime} \mathrm{N}$ $/ 23^{\circ} 40.430^{\prime} \mathrm{W}$, at an elevation of $181 \mathrm{~m}$ above sea level (Fig. 1). The drill rig was assembled directly from the helicopter sling (Fig. 2). Mobilisation of the drill rig and camp took three days, with six tons transported in helicopter sling and cabin loads.
The Blokelv-1 borehole was initiated ('spudded') on 7 August 2008 and completed on 15 August 2008 at a total depth (TD) of $233.8 \mathrm{~m}$. Drilling was carried out using a Diamant Boart 747 wireline rig from Faxe Kalk $\mathrm{A} / \mathrm{S}$, with a casing diameter of $85 \mathrm{~mm}$ and $3 \mathrm{~m}$ long core barrels, yielding high-quality core material with a diameter of $56 \mathrm{~mm}$. Core recovery was $100 \%(1.72-233.8 \mathrm{~m})$. The borehole was abandoned as an open hole with casing down to $20 \mathrm{~m}$. The casing was cemented and closed at the top and a small cairn of sandstone blocks was built over the wellhead. Wires with temperature sensors were
Fig. 3. Aerial view of the drill camp and rig; the well-trodden path leads from the mess tent to the drill site where the water basins are conspicuous.

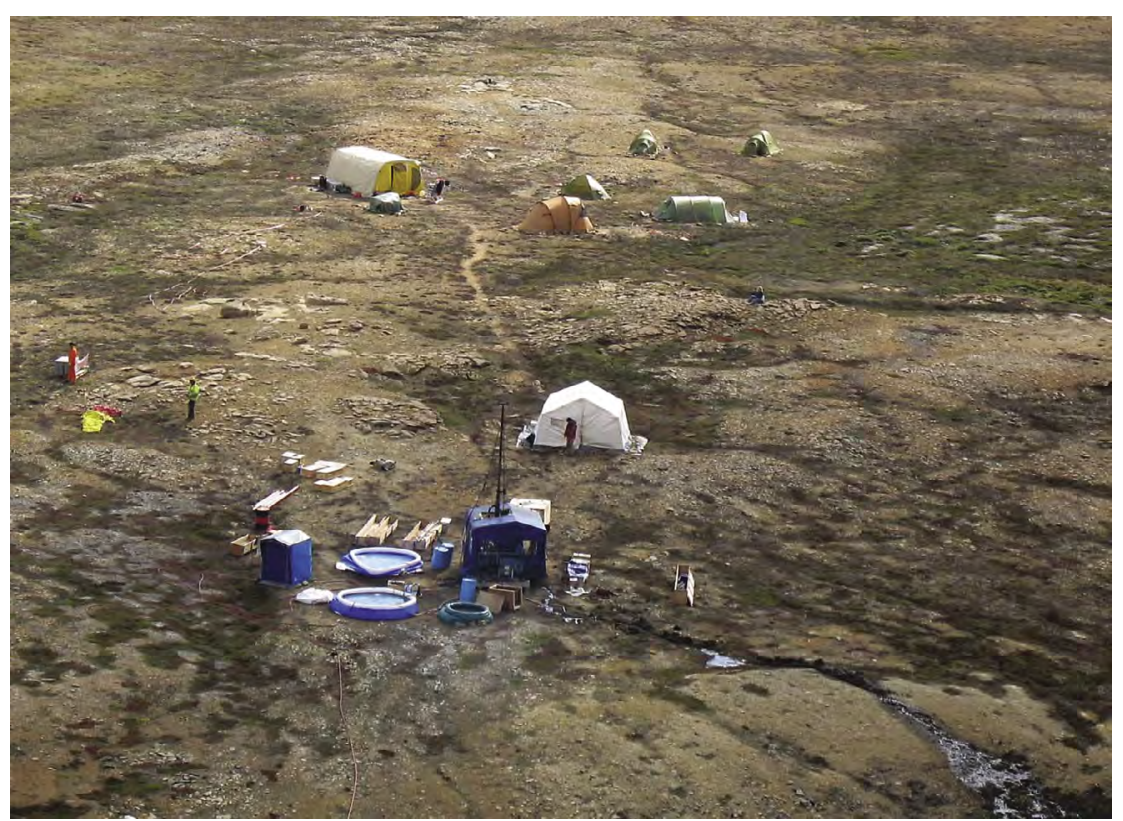




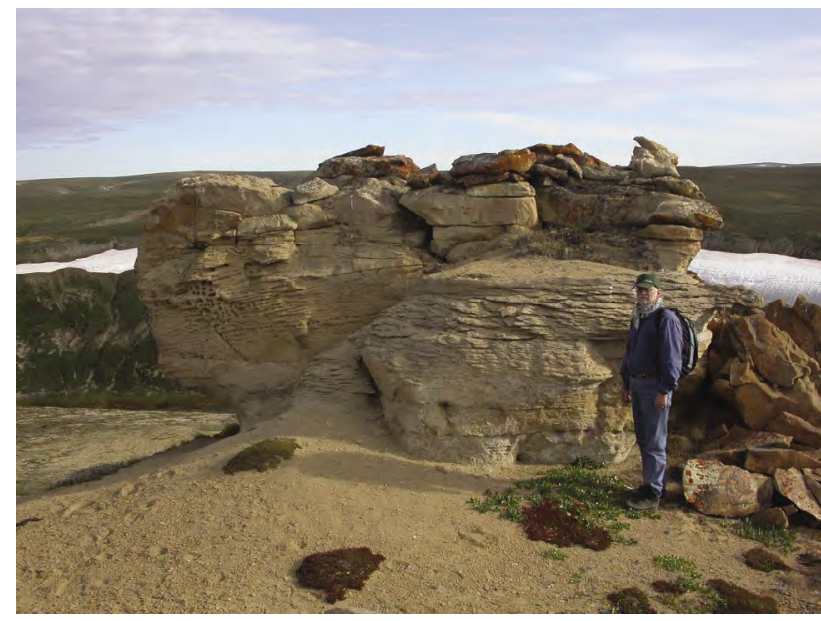

Fig. 4. Outcropping sandstones of the Sjællandselv Member, Hareelv Formation near the drill site.

installed in the hole down to $184 \mathrm{~m}$. Demobilisation and down-hole logging took two days.

Drilling demanded a daily water consumption of 10 $\mathrm{m}^{3}$, with $80 \mathrm{~m}^{3}$ used in total. Water was supplied from the nearest river at about $300 \mathrm{~m}$ lateral distance and $75 \mathrm{~m}$ vertical distance; this was achieved using a petrol-driven water pump and inflatable hoses to supply two 5000-litre basins (Fig. 3). In addition, a 3000 litre basin of saline water was used to circulate through the borehole at night thereby avoiding freezing of the drill string in contact with the permafrost. Permafrost was present from a few decimetres below the surface down to about $100 \mathrm{~m}$. Weather conditions were characteristic of the region being predominantly calm and sunny with temperatures up to $c .20^{\circ} \mathrm{C}$ during the day, interrupted by a few days of fog or low clouds and one day with strong winds.

\section{Drilled succession}

The low plateaux in the terrain around the Blokelv- 1 drill site consist of sandstone of the Upper Jurassic (Lower Volgian) Sjællandselv Member underlain by poorly exposed alternating black mudstone and grey - yellowish grey sandstones of the Katedralen Member of the Hareelv Formation (Figs 4, 5).

The core section has been dated by biostratigraphy, the zonation being based on combined ammonite and dinoflagellate data (Alsen \& Piasecki 2018, this volume). The upper part $(0-10.08 \mathrm{~m})$ is assigned to the Sjællandselv Member of the Hareelv Formation and consists of frac-

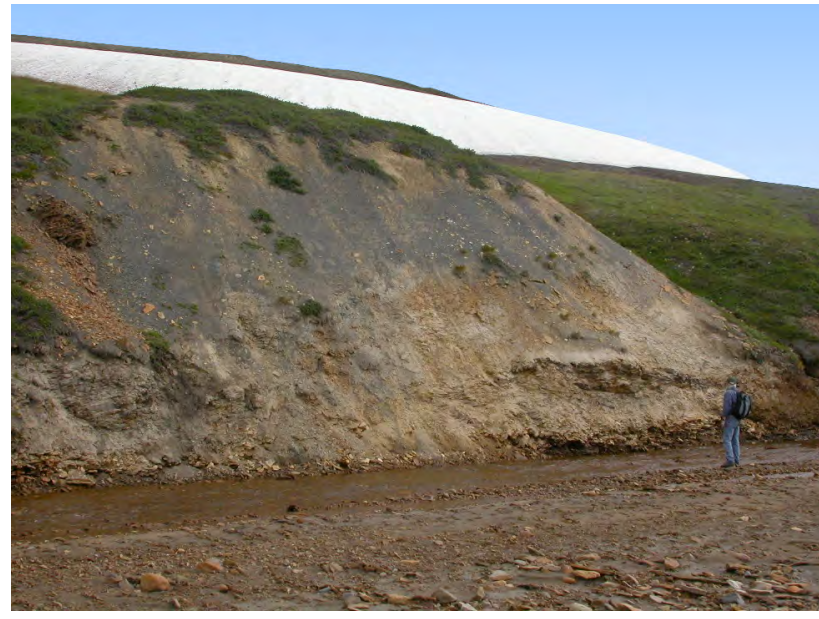

Fig. 5. Poorly exposed mudstones of the Hareelv Formation near the drill site, emphasising the importance of obtaining fresh rock samples in cores for petroleum geological analysis.

tured and structureless, marine gravity-flow sandstones with a few thin very dark grey mudstone beds that contain fossils indicating the lowermost Volgian $P$. elegans Chronozone. The interval from $10.08 \mathrm{~m}$ to TD at 233.8 $\mathrm{m}$ is assigned to the Katedralen Member of the Hareelv Formation, spanning the middle Oxfordian to lowermost Volgian $C$. densiplicatum - P. elegans Chronozones. The cored Katedralen Member comprises very dark grey to black laminated mudstones (54\%), sandstone/mudstone heteroliths (12\%), and weakly stratified - structureless or intrusive sandstones (34\%) (Figs 6, 7). The base of the Hareelv Formation was not reached in the cored interval according to the lithological characteristics, but the lowermost part of the recovered core is assigned to the $C$. tenuiserratum and $C$. densiplicatum Chronozones, which is time equivalent to the upper part of the Olympen Formation (Larsen \& Surlyk 2003; Bruhn \& Surlyk 2004). Possible thin bentonite beds are present at $25.8 \mathrm{~m}, 79.9 \mathrm{~m}$, $83.2 \mathrm{~m}$ and $216 \mathrm{~m}$. Palaeogene intrusions are represented by three sills $(0.7 \mathrm{~m}, 1.2 \mathrm{~m}$ and $1.9 \mathrm{~m}$ thick at depths of about 27,56 and $102 \mathrm{~m}$, respectively) and a dyke $(0.3 \mathrm{~m}$ thick at $c .7 \mathrm{~m}$ depth).

\section{Logging}

A full wireline logging programme was planned to include conductivity, spectral gamma and sonic logs. The borehole was unstable at certain intervals, however, probably due to drilling-induced fractures in homogeneous sandstone. In-hole logging therefore only included 

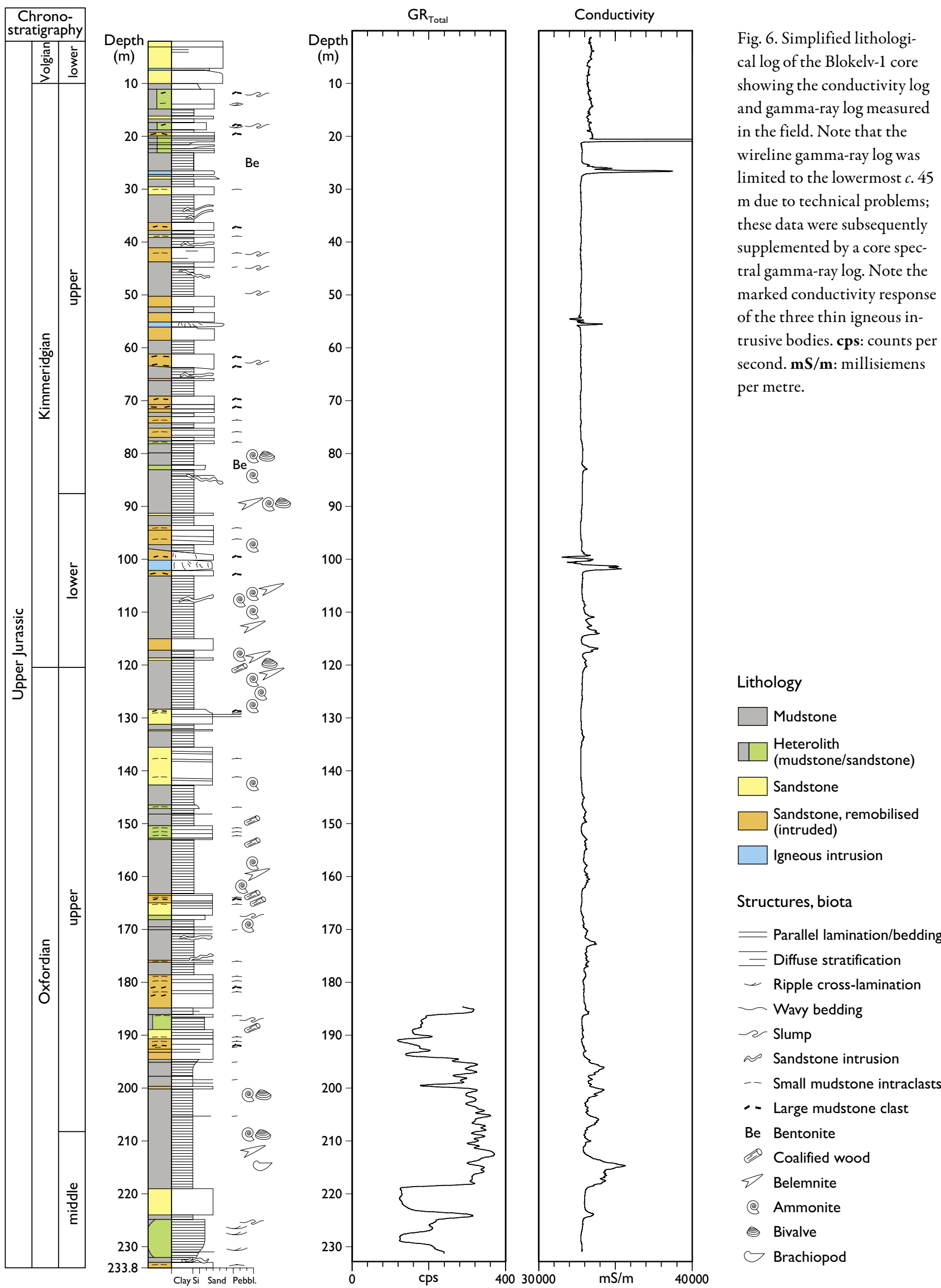

\section{Lithology}

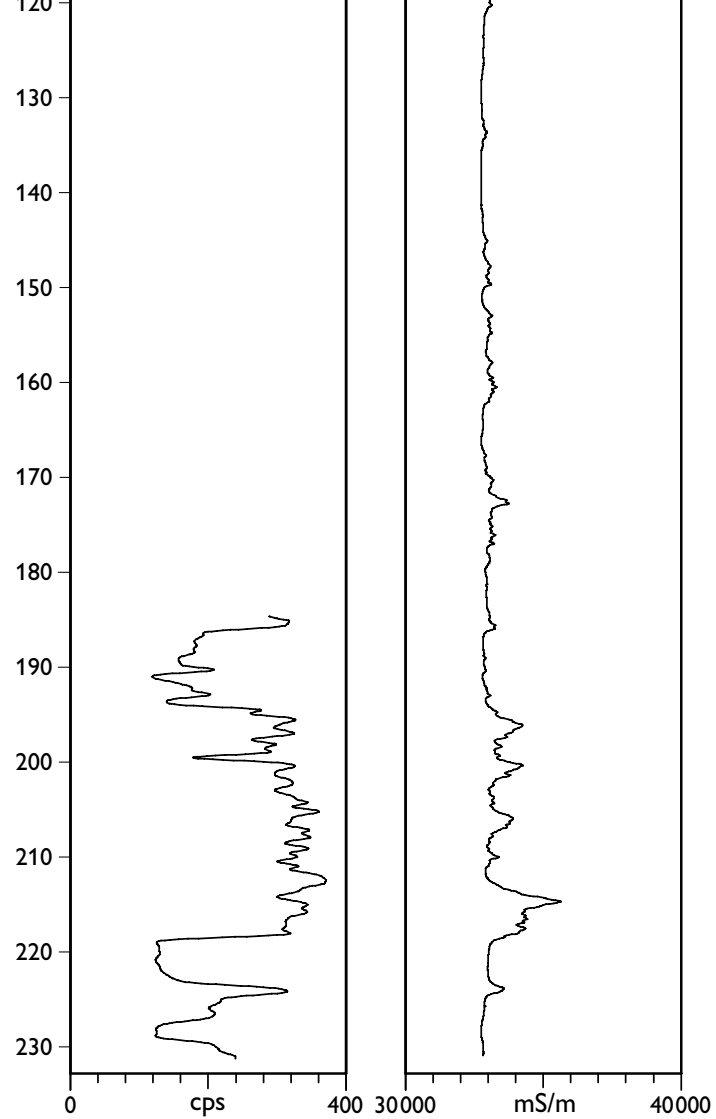

\section{Structures, biota}

\begin{tabular}{|c|c|}
\hline 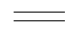 & Parallel lamination/bedding \\
\hline- & Diffuse stratification \\
\hline e & Ripple cross-lamination \\
\hline$\sim$ & Wavy bedding \\
\hline$s$ & Slump \\
\hline$\approx$ & Sandstone intrusion \\
\hline-1 & Small mudstone intraclasts \\
\hline$\cdots$ & Large mudstone clast \\
\hline $\mathrm{Be}$ & Bentonite \\
\hline$\Leftrightarrow$ & Coalified wood \\
\hline$\vartheta$ & Belemnite \\
\hline (a) & Ammonite \\
\hline e) & Bivalve \\
\hline$\circlearrowleft$ & Brachiopod \\
\hline
\end{tabular}




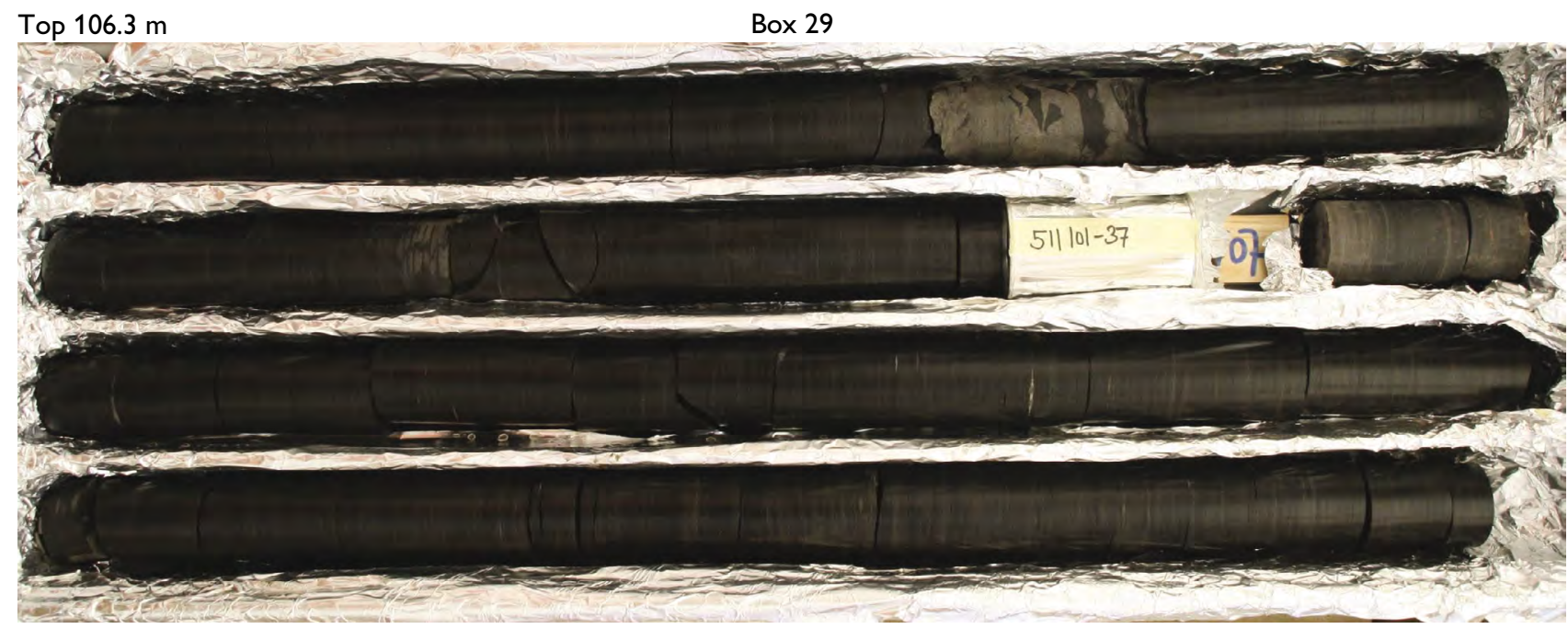

Base 109.85 m

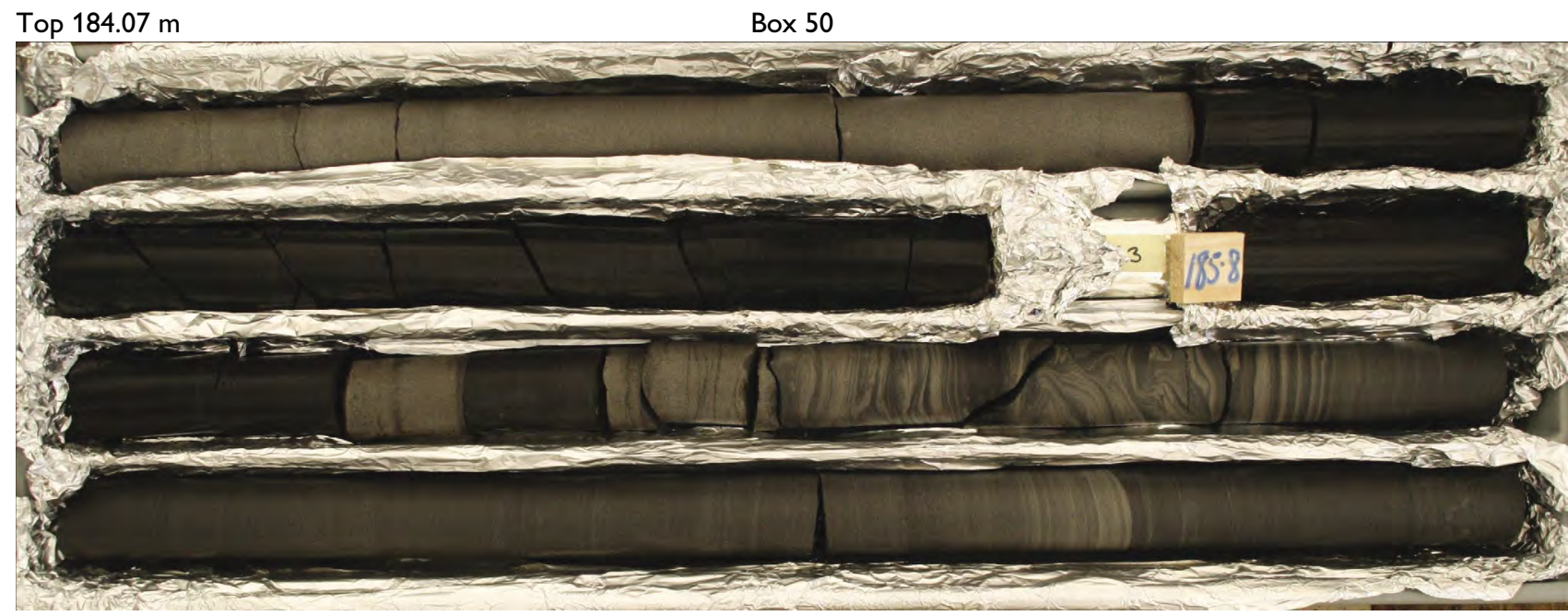

Base $187.95 \mathrm{~m}$

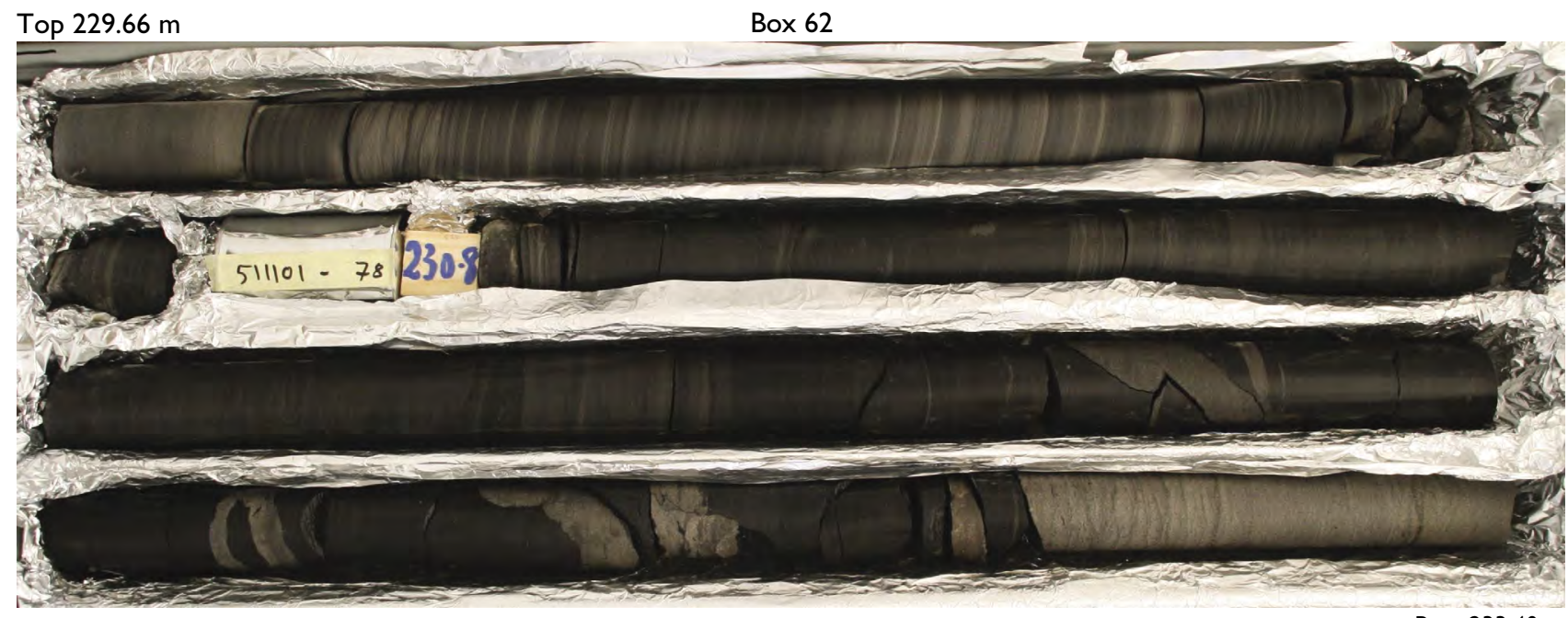

Base $233.40 \mathrm{~m}$

Fig. 7. Core photographs of boxes 29, 50, and 62 showing black organic-rich mudstone, mudstone conglomerate, massive sandstone, laminated heterolithic mudstone-sandstone, slumped heterolithic sandstone-mudstone and sandstone dykes in the Upper Jurassic Katedralen Member (Hareelv Formation). The individual core sections are $1 \mathrm{~m}$ long. 
Table 1. Temperature in the Blokelv corehole, post drilling

\begin{tabular}{ccc}
\hline Depth/m & $\begin{array}{c}\text { Temperature } \\
\text { after } 25.5 \text { hours }\end{array}$ & $\begin{array}{c}\text { Temperature } \\
\text { after } 40.5 \text { hours }\end{array}$ \\
\hline $0 \mathrm{~m}$ & $12.8^{\circ} \mathrm{C}$ & $8.5^{\circ} \mathrm{C}$ \\
$10 \mathrm{~m}$ & $12.5^{\circ} \mathrm{C}$ & $0^{\circ} \mathrm{C}$ \\
$35 \mathrm{~m}$ & $12.0^{\circ} \mathrm{C}$ & $-1.5^{\circ} \mathrm{C}$ \\
$85 \mathrm{~m}$ & $13.0^{\circ} \mathrm{C}$ & $-1.0^{\circ} \mathrm{C}$ \\
$184 \mathrm{~m}$ & $12.7^{\circ} \mathrm{C}$ & $2.2^{\circ} \mathrm{C}$ \\
\hline
\end{tabular}

a complete conductivity log and a partial gamma log (232-184 m depth; Fig. 6). To compensate for this, a high-resolution spectral gamma log and density log of the complete core were later measured in the core laboratory at GEUS (Bjerager et al. 2018a, this volume).

The temperature in the borehole was measured 25.5 and 40.5 hours after drilling ceased at depths of $c .10 \mathrm{~m}$, $35 \mathrm{~m}, 85 \mathrm{~m}$ and $184 \mathrm{~m}$. After 40.5 hours, the temperature stabilised and the estimated depth of the base of the permafrost is at $100 \mathrm{~m}$ (Table 1). Wire and sensors were left in the borehole for later measurements when temperature conditions are in full equilibrium.

\section{Sampling and analytical programme}

At the drill site, 79 full core samples for gas analysis were collected immediately from the bottom of each recovered core (spacing of $3 \mathrm{~m}$ ) and stored in sealed metal cans. In addition, eight samples were collected for preliminary and 'express' biostratigraphic studies immediately after the drilling operation. Three samples of observed bitumen were collected in the cores, including liquid bitumen internally in a belemnite, and solid bitumen along fractures (Bojesen-Koefoed et al. 2018, this volume). Core photographing was conducted under moist and surface-dry conditions. The core was sedimentologically logged at a scale of 1:20 for detailed facies analysis and re-drafted at scales of 1:50 and 1:500 for overview logs (Bjerager et al. 2018a, this volume).

An extensive sampling programme was subsequently conducted in the laboratories at GEUS. Biostratigraphic studies are based on 50 mudstone samples for palynology and 42 levels with ammonites (Alsen \& Piasecki 2018, this volume). Chemostratigraphic and diagenetic studies are based on 42 samples for bulk chemistry, 27 thinsections for petrography, and 22 XRD samples for bulk sample and clay mineralogy (Bjerager et al. 2018a, this volume; Olivarius et al. 2018a, this volume). Provenance studies are based on six samples for identification of heavy minerals and zircon ages (Olivarius et al. 2018b, this volume). Reservoir properties were evaluated on 25 plugs and comprise measurements on grain density, porosity and permeability (Bjerager et al. 2018a, this volume). Petroleum geological evaluation is based on 139 samples for source rock quality and organic maturity with 42 samples for biomarker analysis, 22 samples for stable carbon isotope analyses (Bojesen-Koefoed et al. 2018, this volume). Two samples of igneous intrusions were subjected to major and trace element analysis (Larsen 2018, this volume). Uplift studies were focused on two samples for apatite fission-track analysis (AFTA; Green \& Japsen 2018, this volume).

\section{Acknowledgements}

Logistical assistance from POLOG (J. Weiss Andersen) and Constable Pynt Airport is gratefully acknowledged. Faxe Kalk A/S drillers Peter Turner and Andy Milton skilfully managed the drilling and together with John Boserup and Annette Ryge ran an excellent drilling camp. An AS350 helicopter chartered from Air Greenland transported the drilling equipment from Constable Pynt to the Blokelv-1 drill site. The drilling project was carried out under the auspices of the Petroleum Geological Studies, Services and Data in East and North-East Greenland collaboration agreement. Illustrations were prepared by Jette Halskov and Stefan Sølberg.

\section{References}

Alsen, P. \& Piasecki, S. 2018: Biostratigraphy of the Hareelv Formation (Upper Jurassic) in the Blokelv-1 core, Jameson Land, central East Greenland. In: Ineson, J. \& Bojesen-Koefoed, J.A. (eds): Petroleum geology of the Upper Jurassic - Lower Cretaceous of East and North-East Greenland: Blokelv-1 borehole, Jameson Land Basin. Geological Survey of Denmark and Greenland Bulletin 42, 15-37 (this volume).

Bjerager, M., Alsen, P., Bojesen-Koefoed, J., Kjøller, C., Larsen L.M., Nytoft, H.P., Olivarius, M., Petersen H.I., Piasecki, S. \& Schovsbo, N. 2009: Blokelv Corewell, GGU511101, Upper Jurassic Hareelv Formation in Jameson Land, East Greenland. Danmarks og Grønlands Geologiske Undersøgelse Rapport 2009/86, 3 volumes, 223 pp., 8 appendices.

Bjerager, M., Alsen, P. Bojesen-Koefoed, J.A., Piasecki, S. \& Pilgaard, A. 2018b: Late Jurassic evolution of the Jameson Land Basin, East Greenland - implications of the Blokelv-1 borehole. In: Ineson, J. \& Bojesen-Koefoed, J.A. (eds): Petroleum geology of the Upper Jurassic - Lower Cretaceous of East and North-East Greenland: Blokelv-1 borehole, Jameson Land Basin. Geological Survey of 
Denmark and Greenland Bulletin 42, 149-168 (this volume).

Bjerager, M., Kjøller, C., Olivarius, M., Olsen, D. \& Schovsbo, N. 2018a: Sedimentology, geochemistry and reservoir properties of Upper Jurassic deep marine sediments (Hareelv Formation) in the Blokelv-1 borehole, Jameson Land Basin, East Greenland. In: Ineson, J. \& Bojesen-Koefoed, J.A. (eds): Petroleum geology of the Upper Jurassic - Lower Cretaceous of East and North-East Greenland: Blokelv-1 borehole, Jameson Land Basin. Geological Survey of Denmark and Greenland Bulletin 42, 39-64 (this volume).

Bojesen-Koefoed, J.A., Bjerager, M. \& Piasecki, S. 2009: Shallow core drilling and petroleum geology related field work in North-East Greenland 2008. Geological Survey of Denmark and Greenland Bulletin 17, 53-56.

Bojesen-Koefoed, J.A., Alsen, P. \& Christiansen, F.G. 2014: Six years of petroleum geological activities in North-East Greenland (20082013): projects and a view of the future. Geological Survey of Denmark and Greenland Bulletin 31, 59-62.

Bojesen-Koefoed, J.A., Peter Nytoft, H.P., Petersen, H.I., Piasecki, S. \& Pilgaard, A. 2018: Petroleum potential of the Upper Jurassic Hareelv Formation, Jameson Land, East Greenland. In: Ineson, J. \& Bojesen-Koefoed, J.A. (eds): Petroleum geology of the Upper Jurassic - Lower Cretaceous of East and North-East Greenland: Blokelv-1 borehole, Jameson Land Basin. Geological Survey of Denmark and Greenland Bulletin 42, 85-113 (this volume).

Bruhn, R. \& Surlyk, F. 2004: Sand-grade density flow evolution on a shelf-slope-basin-floor complex in the Upper Jurassic Olympen Formation, East Greenland. Petroleum Geoscience 10, 81-92.

Christiansen, F.G., Gautier, D.L., Stemmerik, L., Bidstrup, T., BojesenKoefoed, J.A. \& Sørensen, K. 2006: Petroleum resource potential of the East Greenland shelf. AAPG Hedberg Research Conference on Understanding World Oil Resources, Colorado Springs, Colorado, USA, 12-17 November 2006. Extended abstract, poster.

Gautier, D.L. 2007: Assessment of undiscovered oil and gas resources of the East Greenland Rift Basins Province. U.S. Geological Survey Fact Sheet 2007-3077, 4 pp.

Gautier, D.L. et al. 2011: Assessment of NE Greenland: prototype for development of Circum-Arctic resource appraisal methodology. Memoir of the Geological Society (London) 35, 663-672.

Green, P.F. \& Japsen, P. 2018: Burial and exhumation history of the Jameson Land Basin, East Greenland, estimated from thermochronological data from the Blokelv-1 core. In: Ineson, J. \& Bojesen-
Koefoed, J.A. (eds): Petroleum geology of the Upper Jurassic Lower Cretaceous of East and North-East Greenland: Blokelv-1 borehole, Jameson Land Basin. Geological Survey of Denmark and Greenland Bulletin 42, 133-147 (this volume).

Larsen L.M. 2018: Igneous intrusions in the cored Upper Jurassic succession of the Blokelv-1 core, Jameson Land Basin, East Greenland. In: Ineson, J \& Bojesen-Koefoed, J.A. (eds): Petroleum geology of the Upper Jurassic - Lower Cretaceous of East and North-East Greenland: Blokelv-1 borehole, Jameson Land Basin. Geological Survey of Denmark and Greenland Bulletin 42, 133-147 (this volume).

Larsen, M. \& Surlyk, F. 2003: Shelf-edge delta and slope deposition in the Upper Callovian - Middle Oxfordian Olympen Formation, East Greenland. In: Ineson, J.R. \& Surlyk, F. (eds): The Jurassic of Denmark and Greenland. Geological Survey of Denmark and Greenland Bulletin 1, 931-948.

Olivarius, M., Bjerager, M., Knudsen, C., Keulen, N., \& Kokfelt, T. 2018b: Provenance of basinal sandstones in the Upper Jurassic Hareelv Formation, Jameson Land Basin, East Greenland. In: Ineson, J. \& Bojesen-Koefoed, J.A. (eds): Petroleum geology of the Upper Jurassic - Lower Cretaceous of East and North-East Greenland: Blokelv-1 borehole, Jameson Land Basin. Geological Survey of Denmark and Greenland Bulletin 42, 115-126 (this volume).

Olivarius, M., Weibel, R., Schovsbo, N.H., Olsen, D. \& Kjøller, C. 2018a: Diagenesis of Upper Jurassic sandstones of the Blokelv-1 core in the Jameson Land Basin, East Greenland. In: Ineson, J \& Bojesen-Koefoed, J.A. (eds): Petroleum geology of the Upper Jurassic - Lower Cretaceous of East and North-East Greenland: Blokelv-1 borehole, Jameson Land Basin. Geological Survey of Denmark and Greenland Bulletin 42, 65-84 (this volume).

Surlyk, F. 2003: The Jurassic of East Greenland: thermal subsidence, onset and culmination of rifting. In: Ineson, J.R. \& Surlyk, F. (eds): The Jurassic of Denmark and Greenland. Geological Survey of Denmark and Greenland Bulletin 1, 659-722.

Surlyk, F., Gjelberg, J. \& Noe-Nygaard, N. 2007: The Upper Jurassic Hareelv Formation of East Greenland: A giant sedimentary injection complex. In: Hurst, A. \& Cartwright, J. (eds): Sand injectites: implications for hydrocarbon exploration and production. AAPG Memoir 87, 141-149. 